\title{
Spatial climate models for Canada's forestry community
}

\author{
by Daniel McKenney', John Pedlar, Michael Hutchinson², Pia Papadopol ${ }^{1}$, Kevin Lawrence ${ }^{1}$, Kathy Campbell ${ }^{1}$, \\ Ewa Milewska ${ }^{3}$, Ron F. Hopkinson ${ }^{4}$ and David Price ${ }^{5}$
}

\begin{abstract}
We summarize ongoing efforts at the Canadian Forest Service to produce spatial climate models for Canada and the United States. Our models, which encompass a wide range of variables and spatiotemporal extents, typically employ thin plate smoothing splines to interpolate and extrapolate climate station values as a function of latitude, longitude and elevation. The resulting surfaces can be resolved as grids (i.e., maps) or as point estimates at locations of interest. Recent efforts, detailed here include: updated models for the most recent 30-year normal period (i.e., 1981-2010), moisture balance models, future climate projections using the latest round of general circulation model (GCM) outputs and emissions scenarios, lake ice freeze/thaw models, and growing season models. These models are available to the Canadian forest community and beyond via the internet (http://cfs.nrcan.gc.ca/projects/3) or by contacting the senior author.
\end{abstract}

Keywords: spatial climate models, lake ice, growing season, future climate projections, climate moisture index, ANUSPLIN

\section{RÉSUMÉ}

Cet article fait le point sur les projets en cours au Service canadien des forêts portant sur lélaboration de modèles climatiques spatialement explicites pour le Canada et les États-Unis. Nos modèles qui comprennent une large gamme de variables et d’amplitudes spatiotemporelles, utilisent généralement des modèles de lissage par plans affinés pour interpoler et extrapoler les valeurs d'une station climatique en fonction de la latitude, de la longitude et de laltitude. Les surfaces ainsi obtenues peuvent être représentées sous forme de quadrillages (par ex., des cartes) ou sous forme destimations ponctuelles pour des endroits particuliers. Les projets les plus récents précisés ci-après comprennent : des modèles actualisés de la plus récente période normale de 30 ans (p. ex., 1981-2010), des modèles de bilan d'humidité, des projections du climat futur utilisant la toute dernière série de données du modèle de circulation générale (GCM) et des scénarios dẻmissions, le modèle de gel et de dégel de la glace des lacs et les modèles simulant la période de croissance. Ces modèles sont à la disposition de la communauté forestière canadienne ainsi que sur l'internet (http://cfs.nrcan.gc.ca/projects/3) ou en communiquant avec l'auteur principal.

Mots clés : modèles climatiques spatialement explicites, glace des lacs, période de croissance, projections du climat futur, indice d’humidité climatique, ANUSPLIN

\section{Introduction}

Climate and weather influences are increasingly recognized as key factors in forest science, management, and planning. However, there is never a weather station where you want it! Hence, for more than two decades, researchers at the Canadian Forest Service have been producing spatial climate models that cover Canada and, in many cases, the United States for a wide variety of variables and time periods. This work has been carried out in collaboration with a number of key partners, including Michael Hutchinson at the Australian National University (ANU) and over the years several staff members at Environment Canada (EC) and the US National Climate Data Centre. While these models were originally developed with forestry applications in mind, they have been employed by agencies and researchers in a variety of other disciplines as well. Here we aim to create further awareness of this work within the forestry community by updating our list of available spatial products from a previous publication (McKenney et al. 2011) and by describing several new efforts, including: climate models for the most recent 30-year normal period (i.e., 1981-2010), lake ice freeze/thaw models, growing season models, and future climate projections from the Coupled Model Intercomparison Project Phase 5 (CMIP5) archive used in the fifth Intergovernmental Panel on Climate Change (IPCC) assessment report.

Throughout this article, we use the term model to describe the mathematical relationship between a climate variable of interest and latitude, longitude, and elevation. All models described here have been generated using thin plate smoothing splines as implemented in the ANUSPLIN climate modelling software (see Hutchinson 1995, 2004 for technical details). A particular advantage of this method is its incorporation of stable dependencies on topography as manifested through position and elevation influences. It has been found to perform well in comparison to other interpolation approaches, particularly in mountainous regions with limited climate station data (Haylock et al. 2008; see also Price et al. 2000). Our modelling approach typically incorporates the following practices: 1) obtaining quality-controlled data from Environment Canada, the National Climate Data Centre in the

\footnotetext{
${ }^{1}$ Natural Resources Canada, Canadian Forest Service, 1219 Queen Street East, Sault Ste. Marie, Ontario P6A 2E5.

${ }^{2}$ Centre for Resource and Environmental Studies, The Australian National University, Canberra ACT 0200 Australia.

${ }^{3}$ Environment Canada, Climate Research Division, Toronto, ON.

${ }^{4}$ Custom Climate Services, Regina, SK.

${ }^{5}$ Natural Resources Canada, Canadian Forest Service, Northern Forestry Centre, 5320 - $122^{\text {nd }}$ Street, Edmonton, Alberta T6H 3S5.

*Corresponding author. E-mail: dan.mckenney@nrcan.gc.ca
} 
United States, and other sources (e.g., http://www.pacificclimate. org/tools-and-data/pcds-portal); 2) testing models with a subset of the full datasets to allow independent model validation whenever possible; 3) examining model diagnostics and residuals after each run to identify potential data and model deficiencies; 4) addressing data and model deficiencies (as effectively as possible given time and budget constraints) and re-running models; and 5) publishing models/maps in peer-reviewed literature and/or on our internet mapper after careful review.

So-called "point estimates" of climate can be obtained at user-supplied locations (such as research sites and growth and yield plots) directly from our Web site (http://cfs.nrcan.gc.ca/ projects/3). Note that if a location of interest is very near a weather station, it may be possible to obtain data directly from an agency like Environment Canada (e.g., http://climate.weatheroffice.gc.ca/climatedata/canada_e.html). Alternatively, the models can be resolved as grids using a digital elevation model (DEM), with the resolution determined by that of the DEM. Historically, we have resolved many models at 5- to $10-\mathrm{km}$ resolutions, which represents a reasonable trade-off between data storage requirements and grid accuracy for many applications. However, finer resolutions are possible (and may be appropriate given the accuracy of the models) and have been generated for specific requests (e.g., watershed-scale studies).

Table 1 summarizes our principal climate surfaces and is an updated version of that found in McKenney et al. (2011). Many of the variables in the table have been modelled for multiple spatial extents and temporal resolutions. For example, minimum temperature, maximum temperature, and precipitation are primary climate variables that are used in a variety of applications and considerable effort has gone into summarizing them in various ways (Table 1). From these primary variables,

Table 1. A summary of the historical climate variables for which models have been generated

\begin{tabular}{|c|c|c|c|c|c|}
\hline Parameter & Units & Time step ${ }^{a}$ & Type $^{\text {b }}$ & Time period covered & $\begin{array}{c}\text { Area } \\
\text { covered }^{c}\end{array}$ \\
\hline \multirow[t]{5}{*}{$\begin{array}{l}\text { Minimum and Maximum } \\
\text { Temperature }\end{array}$} & \multirow[t]{5}{*}{${ }^{\circ} \mathrm{C}$} & $\mathrm{m}$ & $\mathrm{n}$ & $\begin{array}{c}1901-1930^{\mathrm{d}} ; 1901-1950^{\mathrm{d}} ; 1901-2000^{\mathrm{d}} ; 1911- \\
1940^{\mathrm{d}} ; 1921-1950^{\mathrm{d}} ; 1931-1960 ; 1961-1990 \\
1971-2000 ; 1981-2010\end{array}$ & $\mathrm{CA}, \mathrm{NA}$ \\
\hline & & \multirow[t]{3}{*}{$\mathrm{w}$} & $\mathrm{h}$ & $1901-2002$ & $\mathrm{CA}, \mathrm{NA}$ \\
\hline & & & $\mathrm{n}$ & $1961-1990 ; 1971-2000$ & CA \\
\hline & & & $\mathrm{h}$ & $1961-2003$ & $\mathrm{CA}$ \\
\hline & & $\mathrm{d}$ & $\mathrm{h}$ & $1950-2010$ & $\mathrm{CA}$ \\
\hline \multirow[t]{5}{*}{ Precipitation } & \multirow[t]{5}{*}{$\mathrm{mm}$} & $\mathrm{m}$ & $\mathrm{n}$ & $\begin{array}{c}1901-1930^{\mathrm{d}} ; 1901-1950^{\mathrm{d}} ; 1901-2000^{\mathrm{d}} ; 1911- \\
1940^{\mathrm{d}} ; 1921-1950^{\mathrm{d}} ; 1931-1960 ; 1961-1990 \\
1971-2000 ; 1981-2010\end{array}$ & $\mathrm{CA}, \mathrm{NA}$ \\
\hline & & \multirow[t]{3}{*}{$\mathrm{w}$} & $\mathrm{h}$ & $1901-2002$ & $\mathrm{CA}, \mathrm{NA}$ \\
\hline & & & $\mathrm{n}$ & $1961-1990 ; 1971-2000$ & $\mathrm{CA}$ \\
\hline & & & $\mathrm{h}$ & $1961-2003$ & $\mathrm{CA}$ \\
\hline & & $\mathrm{d}$ & $\mathrm{h}$ & $1950-2010$ & $\mathrm{CA}$ \\
\hline Solar Radiation & $\mathrm{MJ} / \mathrm{m}^{2}$ & $\mathrm{~m}$ & $\mathrm{n}$ & $1961-1990 ; 1971-2000$ & CA, NA \\
\hline Sunshine & $\mathrm{h}$ & $\mathrm{m}$ & $\mathrm{n}$ & $1961-1990 ; 1971-2000$ & CA \\
\hline $\begin{array}{l}\text { Potential Evapotranspiration } \\
\text { (simplified Penman-Monteith) }\end{array}$ & $\mathrm{mm}$ & $\mathrm{m}$ & $\mathrm{n}$ & $1961-1990 ; 1971-2000 ; 1981-2010$ & CA, NA \\
\hline Relative Humidity & $\%$ & $\mathrm{~m}$ & $\mathrm{n}$ & 1961-1990; 1971-2000 & CA, NA \\
\hline Vapour Pressure Deficit & $\mathrm{kPa}$ & $\mathrm{m}$ & $\mathrm{n}$ & 1961-1990; 1971-2000; 1981-2010 & CA \\
\hline \multirow[t]{2}{*}{ Climate Moisture Index (CMI) } & \multirow[t]{2}{*}{$\mathrm{cm}$} & \multirow[t]{2}{*}{$\mathrm{m}$} & $\mathrm{n}$ & 1961-1990;1971-2000; 1981-2010 & $\mathrm{CA}, \mathrm{NA}$ \\
\hline & & & $\mathrm{h}$ & $1901-2010$ & $\mathrm{CA}, \mathrm{NA}$ \\
\hline Evaporation (Pan \& Lake) & $\mathrm{mm}$ & $\mathrm{m}, \mathrm{w}$ & $\mathrm{n}, \mathrm{h}$ & $1961-1990$ & CA \\
\hline \multirow[t]{2}{*}{ Extreme Minimum Temperature } & \multirow[t]{2}{*}{${ }^{\circ} \mathrm{C}$} & $\mathrm{a}, \mathrm{m}$ & $\mathrm{n}$ & 1931-1960;1961-1990; 1971-2000; 1981-2010 & NA \\
\hline & & $\mathrm{a}, \mathrm{m}$ & $\mathrm{h}$ & $1951-2010$ & NA \\
\hline \multirow[t]{2}{*}{ Frost Free Days } & \multirow[t]{2}{*}{$\mathrm{d}$} & $\mathrm{a}$ & $\mathrm{n}$ & 1961-1990; 1971-2000; 1981-2010 & $\mathrm{CA}$ \\
\hline & & $\mathrm{a}$ & $\mathrm{h}$ & $1950-2010$ & $\mathrm{CA}$ \\
\hline Average Wind Speed & $\mathrm{km} / \mathrm{h}$ & $\mathrm{m}$ & $\mathrm{n}$ & $1961-1990$ & $\mathrm{CA}, \mathrm{NA}$ \\
\hline Maximum Wind Gust & $\mathrm{km} / \mathrm{h}$ & $\mathrm{m}$ & $\mathrm{n}$ & 1961-1990; 1971-2000; 1981-2010 & CA \\
\hline Rainfall & $\mathrm{mm}$ & $\mathrm{m}$ & $\mathrm{n}$ & $1931-1960 ; 1961-1990 ; 1971-2000 ; 1981-2010$ & $\mathrm{CA}$ \\
\hline Maximum Snow Depth & $\mathrm{cm}$ & $\mathrm{a}$ & $\mathrm{n}$ & 1961-1990; 1971-2000; 1981-2010 & $\mathrm{CA}$ \\
\hline \multirow[t]{2}{*}{ Average Snow Depth } & \multirow[t]{2}{*}{$\mathrm{cm}$} & \multirow[t]{2}{*}{$\mathrm{m}$} & $\mathrm{n}$ & 1961-1990; 1971-2000; 1981-2010 & CA \\
\hline & & & $\mathrm{h}$ & $1955-2010$ & \\
\hline
\end{tabular}

a The time unit of the climate model; $\mathrm{a}=$ annual, $\mathrm{m}=$ monthly, $\mathrm{w}=$ weekly, $\mathrm{d}=$ daily.

${ }^{b}$ The type of climate model; $\mathrm{n}=$ normal (i.e., long-term average), $\mathrm{h}=$ historical (i.e., models generated for each year over a given time period).

${ }^{c} \mathrm{CA}=$ Canada; $\mathrm{NA}=$ Canada and the United States.

dNot all stations used for these models have more than 20 years of records, thus are not true "normals" as defined by the WMO (see Trewin 2007). 
we have calculated a suite of bioclimatic variables and growing season variables (see Table 2 in McKenney et al. 2011) that summarize temperature and precipitation in ways that are potentially important to plants and animals. Spatial models of future climate have also been generated using outputs from a variety of Global Climate Models (GCMs) and emissions scenarios (McKenney et al. 2011, Price et al. 2011). These climate change models have been generated for individual years and averaged for three future time periods to represent short-, medium- and longer-term averages (2011-2040, 2041-2070, and 2071-2100). Recent efforts in this area are detailed below.

\section{New and Updated Models} Historical monthly and daily models

Historical models refer to those produced for each year over a time period of interest. As detailed in Table 1, we have produced historical models of monthly temperature and precipitation for each year starting in 1901 (McKenney et al. 2006), and daily models of temperature and precipitation for each year starting in 1950 (Hutchinson et al. 2009, Hopkinson et al. 2011). These models were recently updated to the year 2010 using ANUSPLIN version 4.37. It is anticipated that updates through 2012 will be completed by Fall 2013. In the past, delayed access to quality controlled climate station data has made it difficult to maintain up-to-date historical climate products. However, this is expected to improve due to efforts by organizations such as the U.S. National Oceanic and Atmospheric Administration's (NOAA) National Climate Data Centre to perform near-real-time quality control operations on global climatology networks including Canada (e.g., Lawrimore et al. 2011).

\section{Models of climate normals}

The World Meteorological Organization defines normals as averages of climatological data for any period of at least 30 consecutive years (Trewin 2007). Our work initially involved the development of climate normals for the 1961-1990 period (McKenney et al. 2001). We have since added various other 30-year periods and most recently the 1981-2010 period (Table 1). In response to recent interest, we have also created 50-year (1901-1950; 1951-2000) and 100-year (1901-2000) average models covering both Canada and the United States (Table 1). Models for the 1981-2010 period employ over 10000 stations across North America ( 3400 stations in Canada) for temperature-related variables and more than 12000 stations for precipitation ( 3600 stations in Canada). These numbers are a vast improvement over station density in the early part of the last century when approximately 1700 stations were available- 500 of which were in Canada.

\section{Climate moisture index models}

The Climate Moisture Index (CMI) is a metric that tracks moisture balance in the absence of soil considerations; positive values indicate an excess of precipitation while negative values indicate a precipitation deficit. It has been presented as a drought index that correlates well with drought-related aspen (Populus tremuloides Michx.) mortality in western Canada (Hogg et al. 2002). Our model employs the CMI formulation presented in Hogg (1994, 1997). Briefly, CMI was calculated by subtracting monthly potential evapotranspiration (PET) from monthly precipitation (P); annual CMI was determined by summing these monthly values. Monthly PET values were calculated using a simplified Penman-Monteith equation, which requires only mean monthly maximum and minimum temperature as detailed in Hogg (1994, 1997). CMI models were generated at annual and monthly time steps for each year over the 1901-2100 period and for several normal periods (Table 1).

\section{Latest climate change scenarios}

Climate projections from a selection of GCMs used for the IPCC's third and fourth climate change assessment reports have been interpolated (see McKenney et al. 2011 and the detailed report by Price et al. 2011). These have been used for various climate change impact and adaptation studies. More recently we have interpolated 12 projections of future climate for the period 2006 to 2100 , derived from the results of the latest generation of GCMs. Four different climate models (from Canada, the USA, the UK and Japan) were selected and results of their simulations driven by three possible trajectories of future greenhouse gas concentrations, as used for the IPCC's fifth assessment report, were obtained from the World Climate Research Program's CMIP5 archive. Projected changes in several climate variables, including solar radiation, wind speed and humidity, as well as temperature and precipitation, covering all of North America (Canada, USA and Mexico) have been extracted, interpolated using ANUSPLIN and converted to time-series of monthly data, totalling over 75000 separate ANUSPLIN models.

\section{Lake ice models}

The timing of lake freeze-up and break-up has important implications for water quality, flooding, lake ecology, recreation, and access to remote locations (Prowse et al. 2008). Of particular importance to forestry is the role of ice in allowing access to remote forest resources during winter harvest operations. Lake ice dynamics have also been identified as valuable indicators of climate change (Magnuson et al. 2000). Over the last half of the $20^{\text {th }}$ century, there was a shortening of the freshwater-ice season across much of Canada, mainly due to earlier spring break-up (Duguay et al. 2006). 
We obtained ice data for 267 lakes from across Canada and the northern United States (north of $42 \mathrm{~N}$ ) over the period 1950 to 2005 from the National Snow and Ice Data Centre (NSIDC; http://nsidc.org/). We examined two approaches for modelling lake freeze-up and break-up dates as a function of climate. First, we developed a script that applied a series of simple climate rules to predict ice freeze/thaw dates; this work employed daily temperature data obtained by interrogating our daily models (Hutchinson et al. 2009) at the location of each lake. The script calculated minimum and maximum daily temperature statistics (e.g., minimum, maximum, mean) for a range of temporal windows (two to 40 days) and then output the dates at which certain thresholds were reached. These dates were compared to actual ice break-up and freeze-up dates in order to identify optimal ice prediction rules. Table 2 shows a summary of optimal predictive rules for ice break-up dates and their associated errors.

Another approach to predicting ice dates is the use of regression models. We employed an existing regression model (Williams et al. 2004) that predicts lake freeze-up and break-up as functions of average monthly temperatures; published errors for this model are 12 days for freeze-up and nine days for break-up. Given the comparable error levels associated with the two approaches and the more straightforward application of the regression model, we chose to employ the regression approach. Thus, the following equations (from Williams et al. 2004) were implemented in a GIS environment using historical monthly climate grids for each year over the 1901 to 2010 period and monthly GCM projections for each year over the 2011 to 2100 period:

[1] Julian Day of Ice Freeze-up $=3.34 \times$ (Average Temperature September 1 to December 31) +324

[2] Julian Day of Ice Break-up $=-4.38 \times$ (Average Temperature February 1 to June 30$)+130$

Maps of average lake freeze-up and break-up dates for the 1971 to 2000 period are shown in Fig. 1. These predictions are probably best interpreted as regional estimates of ice freeze-up and break-up dates; highly accurate estimates at a given lake require lake depth and morphometry information, which is not widely available. However, Williams et al. (2004) provide multivariate equations that do take these factors into consideration; a future update to this work may involve a web tool that resolves these equations for users that provide morphometric data (e.g., surface area and depth) for a lake of interest.

\section{Revised growing season models}

Previous efforts had produced a suite of 16 growing season-related variables as part of our "Seedgrow" package (Mackey et al. 1996). At the time these products were developed, daily climate models were not available, so growing season start and end dates were determined using daily temperature values that were simulated from monthly temperature averages using a cubic spline (or Bessel) interpolation (Mackey et al. 1996). One limitation of this approach was that it produced a smoothed sequence of daily values, which lacked the characteristic variability of actual daily weather conditions and thus introduced bias into the resulting growing season estimates.

Recent efforts have aimed to improve these original growing season products (Pedlar et al. in review). We used our recently developed daily models (Hutchinson et al. 2009) for each year over the 1950 to 2010 period to directly calculate

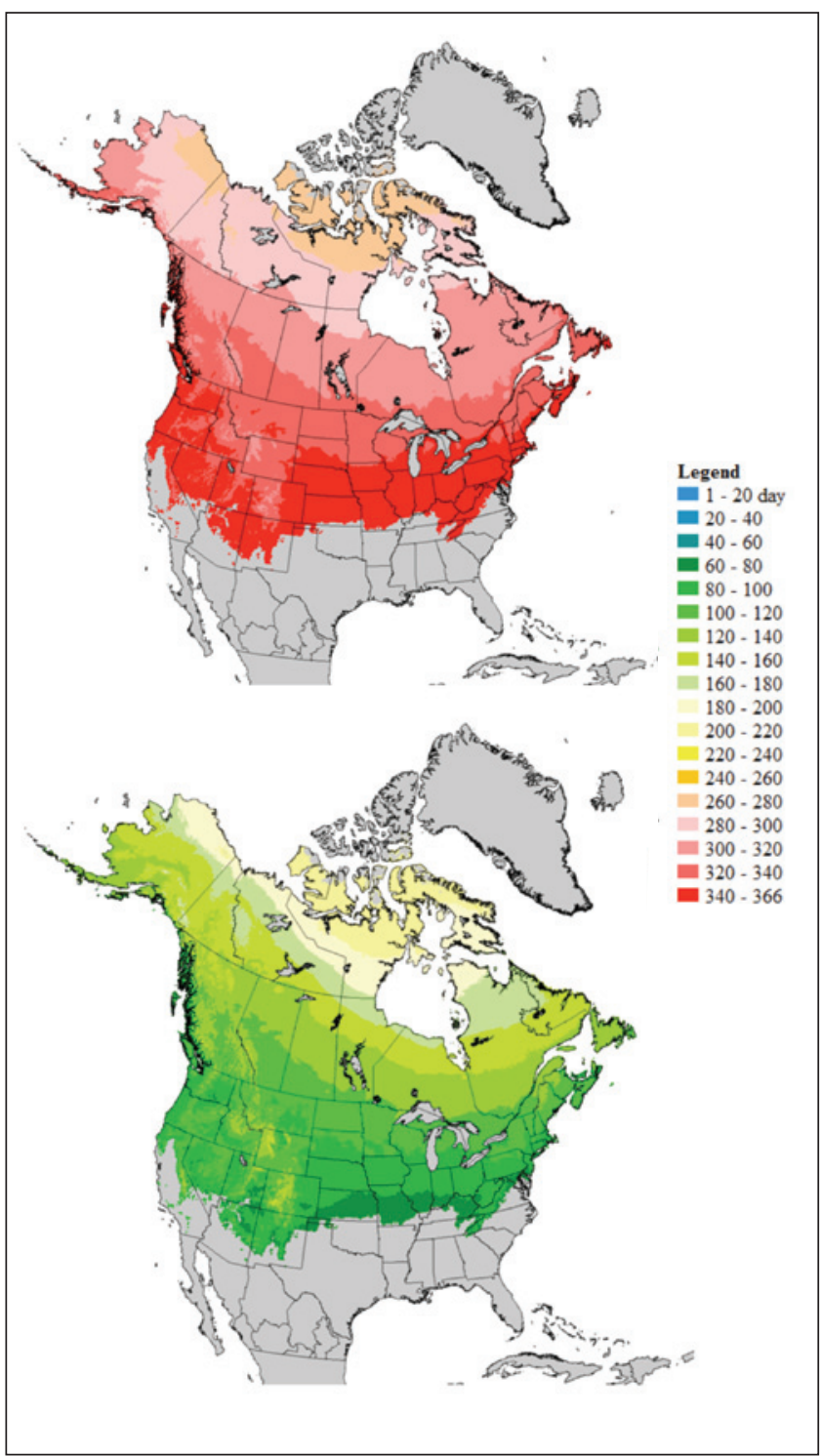

Fig. 1. Average Julian date of lake (a) freeze-up and (b) break-up for the 1971-2000 normal period.

nine growing season variables (Table 3 ). These variables were calculated for each of three minimum temperature thresholds $\left(0^{\circ} \mathrm{C},-2.2^{\circ} \mathrm{C}\right.$, and $\left.-4.4^{\circ} \mathrm{C}\right)$, which were used to define the start/end of the growing season. Since daily grids had not been created for years prior to 1950 nor for GCM projections of future climate, growing season variables were estimated for these periods from a suite of 57 climate and water-related predictors using a modern statistical technique called boosted regression trees (BRT; Friedmann 2002). Errors associated with these products were reasonable; for example, the mean absolute error for growing season start date was about six days for the daily-based product and about 10 days for the BRT approach (see Pedlar et al., in review for full details).

\section{Concluding Comments}

In the forestry community there is a growing demand for spatially reliable climate models at a variety of spatial and temporal resolutions. Indeed there are a growing number of such models available both internationally and for Canada (Kriticos et 
Table 3. Nine variables featured in the revised growing season models

\begin{tabular}{lcl}
\hline Variable & Units & Description \\
\hline Start & days & Julian day of the start of the growing season \\
End & days & Julian day of the end of the growing season \\
Length & days & Duration of the growing season \\
Degree days over $0^{\circ} \mathrm{C}$ & ${ }^{\circ} \mathrm{C}$ & Sum of temperatures over $0^{\circ} \mathrm{C}$ during the growing season \\
Degree days over $5^{\circ} \mathrm{C}$ & ${ }^{\circ} \mathrm{C}$ & Sum of temperatures over $5^{\circ} \mathrm{C}$ during the growing season \\
Degree days over $10^{\circ} \mathrm{C}$ & ${ }^{\circ} \mathrm{C}$ & Sum of temperatures over $10^{\circ} \mathrm{C}$ during the growing season \\
Precipitation & $\mathrm{mm}$ & Total precipitation during the growing season \\
Mean temperature & ${ }^{\circ} \mathrm{C}$ & Average daily temperature during the growing season \\
Temperature range & ${ }^{\circ} \mathrm{C}$ & Range in daily temperatures during the growing season \\
\hline
\end{tabular}

Hutchinson, M.F., D.W. McKenney, K. Lawrence, J.H. Pedlar, R. Hopkinson, E.J. Milewska and P. Papadopol. 2009. Development and testing of Canada-wide interpolated spatial models of daily minimum/maximum temperature and precipitation for 1961-2003. Journal of Applied Meteorology and Climatology 48: 725-741.

Kriticos, D.J., B.L. Webber, A. Leriche, N. Ota, I. Macadam, J. Bathols and J.K. Scott. 2012. CliMond: global high resolution historical and future scenario climate surfaces for bioclimatic modelling. Methods in Ecology and Evolution 3: 53-64.

Lawrimore, J. H., M.J. Menne, B.E. Gleason, C.N. Williams, al 2012, Wang et al 2012). Here we have summarized our own suite of climate products and briefly described several recent modelling efforts. These products will continue to be updated and improved as new data and enhancements to the ANUSPLIN software become available. We hope this note raises awareness of this body of work and encourages potential users to visit the Web site (http://cfs.nrcan.gc.ca/projects/3) or contact us for further information.

\section{Acknowledgements}

We thank several staff of Environment Canada and Natural Resources Canada who have supported and encouraged our work including Bill Hogg, Anna Deptuch-Staph, Robert Vet, and Robert Morris. We also thank Tim Owen of the US National Climate Data Center, Marty Siltanen and Tim Boland of the Canadian Forest Service for their assistance in building particular models.

\section{References}

Duguay, C.R., T.D. Prowse, B.R. Bonsal, R.D. Brown, M.P. Lacroix and P. Menard. 2006. Recent trends in Canadian lake ice cover. Hydrol. Process. 20: 781-801.

Friedman, J.H. 2002. Stochastic gradient boosting. Computational Statistics and Data Analysis 38: 367-378.

Haylock, M.R., N. Hofstra, A.M.G. Klein Tank, E.J. Klok, P.D. Jones and M. New. 2008. A European daily high resolution gridded data set of surface temperature and precipitation for 1950-2006. Journal of Geophysical Research 113, D20119. doi:10.1029/2008JD010201.

Hogg, E.H. 1994. Climate and the southern limit of the western Canadian boreal forest. Canadian Journal of Forest Research 24: 1835-1845. Hogg, E.H. 1997. Temporal scaling of moisture and the forestgrassland boundary in Western Canada. Agricultural and Forest Meteorology 84: 115-122.

Hogg, E. H., J.P. Brandt and B. Kochtubajda. 2002. Growth and dieback of aspen forests in northwestern Alberta, Canada, in relation to climate and insects. Canadian Journal of Forest Research 32: 823-832.

Hopkinson, R. F., D.W. McKenney, E.J. Milewska, M.R. Hutchinson, P. Papadopol and L.A. Vincent. 2011. Impact of aligning climatological day on gridding daily maximum-minimum temperature and precipitation over Canada. Journal of Applied Meteorology and Climatology 50: 1654-1665.

Hutchinson, M.F. 1995. Interpolation of mean rainfall using thin plate smoothing splines. International Journal of Geographic Information Systems 9: 385-403.

Hutchinson, M.F. 2004. ANUSPLIN Version 4.3. Centre for Resource and Environmental Studies, Australian National University. Available at http://cres.anu.edu.au/outputs/anusplin.php
D.B. Wuertz, R.S. Vose and J. Rennie. 2011. An overview of the Global Historical Climatology Network monthly mean temperature data set, version 3. Journal of Geophysical Research 116: D19121. doi:10.1029/2011JD016187.

Magnuson, J. J., D.M. Robertson, B.J. Benson, R.H. Wynne, D.M. Livingstone, T. Arai and V.S. Vuglinski. 2000. Historical trends in lake and river ice cover in the Northern Hemisphere. Science 289: 1743-1746. Hutchinson. 1996. Site regions revisited: a climatic analysis of Hills' site regions for the province of Ontario using a parametric method. Canadian Journal of Forest Research 26: 333-354.

McKenney, D.W., M.F. Hutchinson, J.L. Kesteven and L.A. Venier. 2001. Canada's plant hardiness zones revisited using modern climate interpolation techniques. Canadian Journal of Plant Science 81: 129-143.

McKenney, D. W., M.F. Hutchinson, P. Papadopol, K. Lawrence, J.H. Pedlar, K. Campbell, E. Milewska, R. Hopkinson, D. Price and T. Owen. 2011. Customized spatial climate models for North America. Bulletin of the American Meteorological Society 92: 1611-1622.

McKenney, D. W., J.H. Pedlar, P. Papadopol and M.F. Hutchinson. 2006. The development of 1901-2000 historical monthly climate models for Canada and the United States. Agricultural and Forest Meteorology 138: 69-81.

Pedlar, J.H., D.W. McKenney, K. Lawrence, P. Papadopol and M.F. Hutchinson. 2013. Spatial models of growing season variables for Canada. In review.

Price, D.T., D.W. McKenney, L.A. Joyce, R.M. Siltanen, P. Papadopol and K. Lawrence. 2011. High-resolution interpolation of climate scenarios for Canada derived from General Circulation Model simulations. Nat. Resour. Can., Can. For. Serv., North. For. Cent., Edmonton, AB. Inf. Rep. NOR-X-421. 104 p.

Price, D.T., D.W. McKenney, I.A. Nalder, M.F. Hutchinson and J.L. Kesteven. 2000. A comparison of two statistical methods for spatial interpolation of Canadian monthly mean climate data. Agricultural and Forest Meteorology 101: 81-94.

Prowse, T.D., B.R. Bonsal, C.R. Duguay, D.O. Hessen and V.S. Vuglinsky. 2008. River and Lake Ice. Chapter 8 in Global Outlook for Ice and Snow. United Nations Environment Programme, Arendal, Norway.

Trewin, B. 2007. The role of climatological normals in a changing climate. WMO-TD No. 1377. World Meteorological Organization, Geneva.

Wang, T., A. Hamann, D.L. Spittlehouse and T.Q. Murdock. 2012. ClimateWNA - High-resolution spatial climate data for western North America. Journal of Applied Meteorology and Climatology 51: 16-29. Williams, G., K.L. Layman and H.G. Stefan. 2004. Dependence of lake ice covers on climatic, geographic and bathymetric variables. Cold Regions Science and Technology 40: 145- 164.
Mackey, B. G., D.W. McKenney, Y.Q. Yang, J.P. McMahon and M.F. 